\title{
STUDENTS INTERESTS TOWARDS SCIENCE FIELDS ABOUT EXHIBITIONS IN SCIENCE CENTERS: FEZA GURSEY SCIENCE CENTER IN TURKEY
}

\section{Aykut Emre Bozdogan}

Ahi University, Education Faculty Department of Science Education, Kirsehir, Turkey

\begin{abstract}
In this study, it was attempted to obtain information from their drawings about which science fields the students, visiting Feza Gursey Science Center (FGSC), were interested in the most. The research was performed in 5 primary schools which visited FGSC in Ankara in 2005 and it took 4 weeks. One hundred and twenty-two students from $6^{\text {th }}, 7^{\text {th }}$ and $8^{\text {th }}$ grades were evaluated in this study. In obtaining interests of students from $6^{\text {th }}, 7^{\text {th }}$ and $8^{\text {th }}$ grade towards science fields after the exhibitions in the FGSC, "drawing" method which is a qualitative approach was used. As a result of this research, it is found that students who visited FGSC are mostly interested in physics a science field, and biology, chemistry and astronomy fields follow this. It was also noted that only 24 out of 122 students who attended the research knew the name of exhibition or activity which he drew about.

Key words: science centers, informal learning, science education.
\end{abstract}

\section{Introduction}

At present, education activities have turned into a process which continues through the lifetime at home, in the school, work and in every possible place and opportunity. Informal learning environments are required to teach the new knowledge obtained from the rapid improvements in science and technology to the increasing number of people with a simple, understandable and enjoyable way.

Informal learning environments include many social fields that allow students to have individual relationships with real objects and thus provide them to gain permanent knowledge through a positive attitude, values and points of view. Such environments include some mass media tools like television, radio, newspapers, magazines and internet, and sport centers, science centers, science and technology museums, natural history museums, zoos, botanic parks, forests, libraries, aquariums, open air laboratories, nature centers (caves, lakes, rivers, shores etc.), camps and houses (Davies, 1997; Hannu, 1993; Kelly, 2000; Martin, 2004; Pedretti, 2004).

Studies performed have shown that the activities outside of formal education have effects on the improvement of experiences obtained in school (Gerber, Cavallo \& Marek, 2001; Hannu, 1993). Maybe the most important one of these informal learning environments is science centers, since science centers are among rare places that present science, technology and education together. Science centers have a structure capable of contributing to science education and professional education by building bridges between both science-education and technology-education.

Science centers are ideal places for adding benefits to especially primary school students' intelligence, emotional and psychomotor improvements in our today's education system which consists advocate of change, collective and student centered applications and students' needs are considered in, because science centers allow visitors freely discover, learn by themselves, interact in groups and share experiences (Lemelin \& Bencze, 2004; RameyGassert, 1997; Rapp, 2005). In exhibitions and education programs arranged thus, students particularly use their hands and logic, have interaction with the world, come to conclusions by studying collaboratively, discuss, observe, have experiences and increase their understanding capacity (Rapp, 2005; Livingstone, Pedretti \& Soren, 2001; Barshinger \& Ann, 1998). 
Science centers that address individuals of all ages have many educational programs such as lessons to provide individual learning, demonstrations, interactive activities, games and visional materials. Thus, they give visitors the chance of gaining science literacy from the first hand (Yu, 1999). Wellington (1990), determined that interactive science centers have great effects on establishing links between the equipments used and seen during daily life and science and technology, on getting to like science and science literacy. In addition, in studies on museum-education connection in the last 30 years, it has been shown that science centers complement the subjects in school science courses, improve science skills of students of especially $5^{\text {th }}-8^{\text {th }}$ grades, increase their success in science and improve their attitude towards science and make it easy to learn by refreshing their curiosity for science. (Guisasola, Morentin \& Zuza, 2005; Griffin, 2004; Chin, 2004; Cox-Petersen, 1999). It was also found that students improved their social skills by using oral communication activities during the tours (Panizzon \& Gordon, 2003). Paris, Yambor and Packard (1998) examined the effects of student activities outside schools on interests in biology and their knowledge level. In this study, it was found that there is a certain increase in the level of interest of student for science and a certain improvement in problem solving skills of students in all grades. Jarvis and Pell (2002) observed the experiences of 650 primary school students who visited British Space Center from the simulations in this center and examined their attitude towards science and space. As a result of the tests they took immediately after the tour and 5 months later, it was stated that there was a positive increase in students' attitude towards science and space but only $24 \%$ of the students wished to make a scientific career in these fields in the future. The change in attitudes continued throughout many months and these students said that they are eager to science. Falk and Adelman (2003) questioned in what level informal science learning institutions such as science centers, zoos, aquariums and natural history museums reached their goal. The changes in visitors' knowledge and attitudes were observed in National Baltimore Aquarium. The results of the research showed a positive improvement occurred in visitors' knowledge and attitudes. Tenenbaum, Rappolt-Schlichtmann and Zanger (2004), investigated the effects of school and museum collaboration on science learning of students with low income levels. In this study, they stated that science centers are effective on the improvement of students' science literacy, and exhibitions and activities in the science museum positively affected the students' attitudes towards science. In their research about the effects of usage of science centers in science lessons to students' interests in science, Bozdogan and Yalcin (2007) showed that science centers have significant effects on the increase in students' interests for science in their study they investigated the effects of using science centers in science courses on the level of interest of the students for science.

It has been shown with studies performed that science centers increase students' interests in science courses, which students have difficulties in understanding and therefore describe them as difficult and boring, and improve their attitude. In this study, it was attempted to determine from their drawings the science fields that the students visiting Feza Gursey Science Center (FGSC) are interested most.

The purpose of study: with this research, the interests of students from $6^{\text {th }}, 7$ th, and $8^{\text {th }}$ grades of primary school towards science fields were examined within the frame of FGSC exhibitions.

\section{Methodology of Research}

\section{Participants}

The research was carried out in 5 primary schools visiting FGSC [school A, $(n=26)$; school B, $(n=24)$; school C, $(n=23)$; school D, $(n=26)$ and school E, $(n=23)]$ in Ankara in 2005 and it took 4 weeks. Total 122 students (59 boys and 63 girls) from $6^{\text {th }}, 7^{\text {th }}$ and $8^{\text {th }}$ grades 
participated in the research. 45 of these students visited FGSC within the last 6 months, 50 of them visited within the last 12 months and 27 of them visited within the last 18 months.

\section{Experiment Design}

To learn about the interests of students from $6^{\text {th }}, 7^{\text {th }}$ and $8^{\text {th }}$ grade towards science fields within the frame of exhibitions in the FGSC, "drawing" method which is a qualitative approach was used as data collection method. Drawing method is generally used in studies that aim obtaining individuals' ideas and conceptual structures about any subject (White \& Gunstone, 1992). In the present study, the students were asked to draw the most interesting interactive exhibition in FGSC they visited and to write the names of exhibitions and explain them.

In the research, the drawings of primary school students are classified according to the predetermined classification in FGSC exhibitions as physics, chemistry, biology and astronomy and it is tried to obtain students interest fields (Table 1). In the study, the number of drawings belonging to the each group was determined and presented in frequencies. Common expressions in students' writings from these groups were also collected in findings part. In addition to this, the relation between sex and grade levels of students attending research and science fields that they interested in was examined with the chi-squared method for two variables from non- parametric statistics.

Table 1. The classification of major exhibitions and activities in FGSC according to science fields.

\begin{tabular}{|c|c|c|c|}
\hline Field & & bition and activity & Explanation \\
\hline \multirow{6}{*}{ Physics } & 1 & $\begin{array}{c}\text { Electric } \\
\text { Demonstration }\end{array}$ & $\begin{array}{l}\text { - In this demonstration that the working principle of Van } \\
\text { de Graaff generator is explained, a potential approximately } \\
500.000 \text { volt is established and its effects are observed. }\end{array}$ \\
\hline & 2 & Hot air Balloon & $\begin{array}{l}\text { - It is aimed to give information about how hot air balloon } \\
\text { works, the relation between air and heat, and balloons. }\end{array}$ \\
\hline & 3 & Whispering Dishes & $\begin{array}{l}\text { - It is demonstrated how sound waves produced in the } \\
\text { focal point of the dish become audible by being collected } \\
\text { in the focal point of the other dish. }\end{array}$ \\
\hline & 4 & Plasma Ball & - Plasma state of the matter is introduced to the visitors. \\
\hline & 5 & Bicycle generator & $\begin{array}{l}\text { - This is the experimental set, in which mechanic energy } \\
\text { is transferred to electric energy. }\end{array}$ \\
\hline & 6 & $\begin{array}{c}\text { Aerodynamic } \\
\text { bicycle }\end{array}$ & $\begin{array}{l}\text { - This is the mechanism that shows approximately how } \\
\text { much watt energy you have when the pedals are cycled. }\end{array}$ \\
\hline \multirow{3}{*}{ Chemistry } & 1 & $\begin{array}{c}\text { Nitrogen } \\
\text { Demonstration }\end{array}$ & $\begin{array}{l}\text { - It is the demonstration in which properties of liquid } \\
\text { nitrogen which has }-196^{\circ} \mathrm{C} \text { temperature is shown. }\end{array}$ \\
\hline & 2 & Bernoulli Blower & $\begin{array}{l}\text { - Information about the low pressure areas, high pressure } \\
\text { areas and the aerodynamic properties of planes are given } \\
\text { by visitors' own practices. }\end{array}$ \\
\hline & 3 & Shadow Tunnel & $\begin{array}{l}\text { - This is the set which proves it is even possible to } \\
\text { photograph a shadow. }\end{array}$ \\
\hline \multirow{3}{*}{ Astronomy } & 1 & Astronomy Slide & $\begin{array}{l}\text { - This is the slide demonstration in which space and some } \\
\text { of its secrets are introduced. }\end{array}$ \\
\hline & 2 & Black hole Model & $\begin{array}{l}\text { - In this exhibition unit, information about black holes is } \\
\text { given and visitors are given the opportunity to observe the } \\
\text { movements of planets caught by attraction of a black hole } \\
\text { and how it is swallowed by black hole. }\end{array}$ \\
\hline & 3 & Galaxy Research & $\begin{array}{l}\text { - It is the exhibition in which galaxies and stars of Virgo } \\
\text { Cluster can be observed. }\end{array}$ \\
\hline
\end{tabular}




\begin{tabular}{|c|c|c|c|}
\hline \multirow{4}{*}{ Biology } & 1 & Microscope & $\begin{array}{l}\text { - Same } 25 \text { examples such as fruit fly, fish scale, snake } \\
\text { skin and newspaper paper are shown with } 3 \text { microscopes. }\end{array}$ \\
\hline & 2 & $\begin{array}{l}\text { Human body } \\
\text { Model }\end{array}$ & $\begin{array}{l}\text { - On this plastic anatomic human model that internal } \\
\text { organs can be dismounted and mounted back, the skeleton, } \\
\text { muscles, circulation, and lymphatic, respiration, digestion, } \\
\text { hormonal, excretion and reproduction systems can be } \\
\text { observed in whole details. }\end{array}$ \\
\hline & 3 & $\begin{array}{l}\text { Human heart and } \\
\text { lung }\end{array}$ & $\begin{array}{l}\text { - Some general information is given about human heart, } \\
\text { veins and lung on organs taken from cadaver and specially } \\
\text { preserved. In addition, the lungs of people who smoke and } \\
\text { who don't smoke are compared. }\end{array}$ \\
\hline & 4 & Little Man Model & $\begin{array}{l}\text { - This is the model representing the brain as a body and } \\
\text { shows the proportion of each part to its proportion in the } \\
\text { brain that controls its sense and movement duties. This } \\
\text { model is presented in the entrance of science center. }\end{array}$ \\
\hline
\end{tabular}

\section{Learning Environment}

After Ankara Metropolitan Municipality signed an agreement with authorities of Ontario Science Centre (OSC) in 1992, the progress of building the first and only science center of Turkey started. Forty-eight experimental packs that cost 2.3 million dollars were purchased for the science center. In the process of establishment of the science center with the cooperation of the university museum, the selection of experiment and exhibition units was performed by considering the needs of education and curriculum in Turkey and giving weight to sets particularly in the field of basic sciences. The recommendation of the Ministry of Education of the science center to the students of primary and secondary schools on $25^{\text {th }}$ January 1995 shows that how the selection fits.

The name of Feza Gursey, one of the foremost physicists of Turkey and the world, died in 1992, was given to the science center. Feza Gursey Science Center was put into service on $23^{\text {rd }}$ April 1993 with the assistance of Ankara Metropolitan Municipality.

More than 1.2 million people visited the science center between 1994 and 2005. In this center with a $1000 \mathrm{~m}^{2}$ experimental area and $2000 \mathrm{~m}^{2}$ total area, 7 personnel and guides with a number varying between 10 and 20 are employed. The guides working in the science center working part time or full time are young people graduated from the university or under graduates in physics, chemistry, biology, science, astronomy, mathematics, computer and geology departments of the universities. The science center working with appointment system gives free service to the students of Ankara city center and districts. Ankara Metropolitan Municipality also provides free transportation to the schools that come to science center.

FGSC serves for the aim of introducing, pleasing with and assisting to comprehend the basic principles of science by doing experiments and especially in an entertaining environment helping students to understand and apply what they learn theoretically in science courses. Because of this, each unit designed in an appropriate form to let visitors do the experiment and observe individually.

\section{Data Collection and Analyses}

Data collection of the research and analyses of the obtained data is gradually explained in Table 2 . 
Table 2. The application steps of the study.

\begin{tabular}{|c|c|}
\hline Step & Process \\
\hline 1 & $\begin{array}{l}12 \text { of the central primary schools visiting FGSC in Ankara in October } 2005 \text { were chosen } \\
\text { randomly. Data were obtained by interviewing with the } 26 \text { science teachers from these schools. }\end{array}$ \\
\hline 2 & $\begin{array}{l}\text { As a result of these interviews, } 7 \text { schools, which prepared a tour plan for the visit to science center } \\
\text { and related the tour with lessons, were eliminated from the research. Five other primary schools } \\
\text { visiting the science center for only entertainment with the accompaniment of guides were } \\
\text { included to the research. The reason for this is to ensure that students reflect their own interests } \\
\text { and ideas without being under the effect of teacher and the tour program. }\end{array}$ \\
\hline 3 & $\begin{array}{l}\text { In this study students are asked "Can you draw the most interesting exhibition or activity in the } \\
\text { science center in your opinion?", "Can you write the name of the exhibition or activity that you } \\
\text { draw?" and "Can you explain the Picture that you draw?" }\end{array}$ \\
\hline 4 & $\begin{array}{l}\text { Exhibitions and activities in the FGSC were classified under } 5 \text { titles as "Physics", "Chemistry", } \\
\text { "Biology", "Astronomy" and "Technology" by } 2 \text { experts. Data obtained from the students" } \\
\text { drawings were also classified under these titles (Table 1). As a result of this classification, the } \\
\text { field of science that students were interested in within the frame of exhibitions and activities in the } \\
\text { science centers were determined. }\end{array}$ \\
\hline
\end{tabular}

\section{Results of Research}

Science fields that students visiting FGSC were interested in most were examined and are given in the Tables 3, 4, 5 and 6 .

Table 3. The distribution of students as regards interesting activities and exhibitions on Physics in FGSC.

\begin{tabular}{cllc}
\hline Field & & \multicolumn{1}{c}{ Exhibition and activity } & f \\
\hline & 1 & Electric Demonstration & 27 \\
Physics & 2 & Plasma Ball & 8 \\
& 3 & Hot Air Balloon & 8 \\
& 4 & Bicycle Generator & 8 \\
& 5 & Aerodynamic Bicycle & 8 \\
& 6 & Whispering Dishes & 7 \\
& & & Total \\
\hline
\end{tabular}

Table 3 is shown that students visited FGSC were interested mostly $(n=66)$ in activities and exhibitions about physics field of science. It is seen that students are interested in exhibitions and activities with the names "Electric Demonstration" (figure 1 and figure 2), "Plasma Ball" (figure 3 and figure 4), "Hot Air Balloon" (figure 5), "Bicycle Generator", "Aerodynamic Bicycle" (figure 6 and figure 7) and "Whispering Dishes" (figure 8) in the physics field.

Students' drawings about their interests in exhibitions and activities in physics field are given below. 


\section{Children's Perspectives of FGBM Settings and Experiences About Physics}

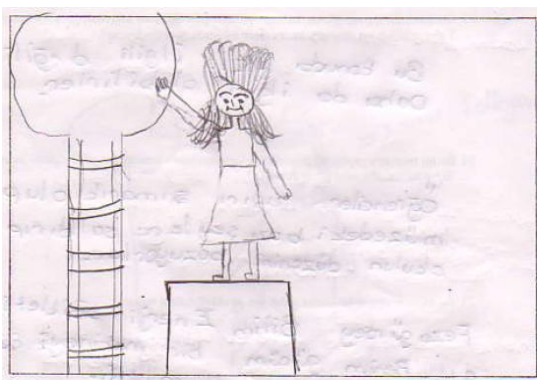

Figure 1. "When static electric is given to the human body, his hair stands erect but it doesn't harm. The erection of our hair by using Van de Graff generator interested me a lot." $\mathrm{F}_{7}, 6^{\text {th }}$ grade.

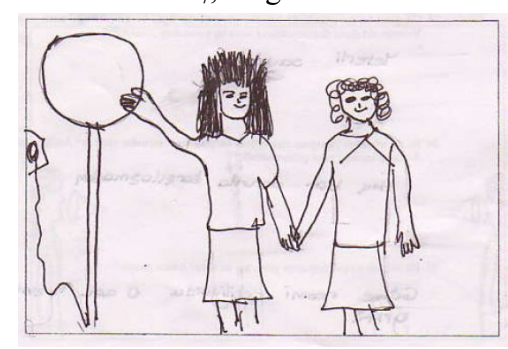

Figure 2. "My friends touching an electric bulb and raise and erection of their hair amused me." $\mathrm{F}_{104}, 8^{\text {th }}$ grade.

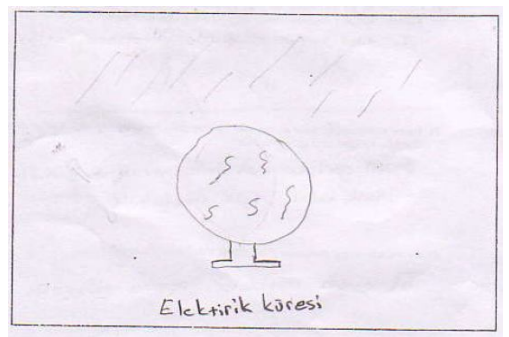

Figure 3. "I learned that there are 4 states of the matter. Plasma ball which shows the $4^{\text {th }}$ state was very interesting." $\mathrm{M}_{81}, 6^{\text {th }}$ grade.

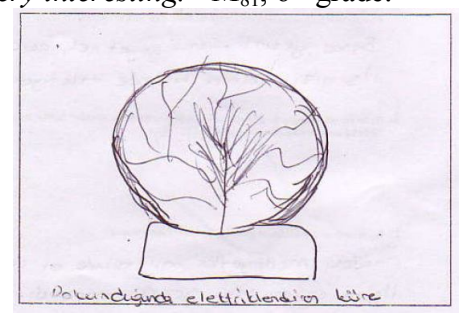

Figure 4. "There was a globe like equipment that produced electricity when touched. When you touch it, it shines from inside. This interested me a lot." $\mathrm{F}_{97}, 8^{\text {th }}$ grade.

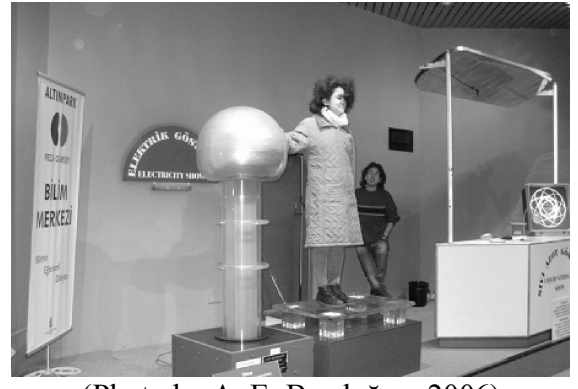

(Photo by A. E. Bozdoğan, 2006)

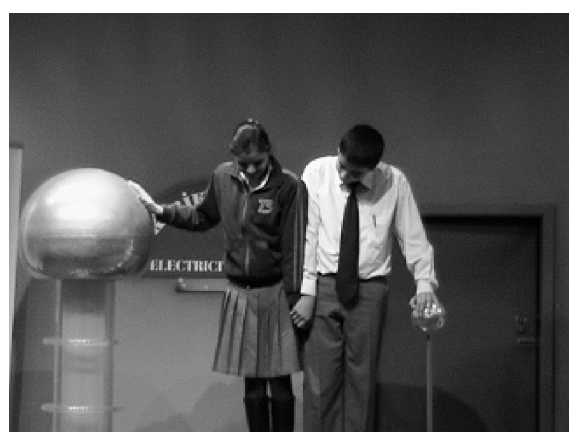

(Photo by A. E. Bozdoğan, 2006)

The Electric Demonstration

In which the working principle of Van de Graaff generator was told

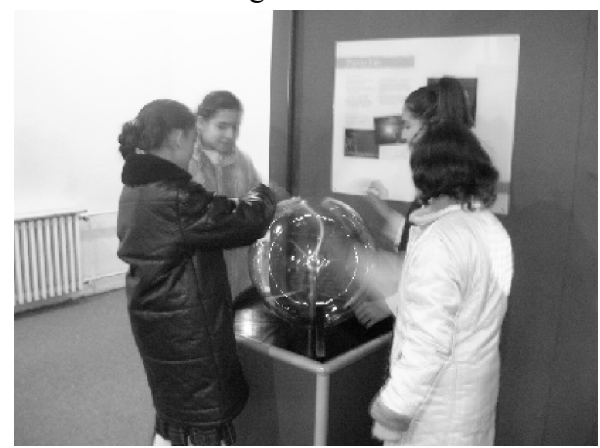

(Photo by A. E. Bozdoğan, 2006)

Plasma Ball exhibition

where the Plasma state of the matter is introduced 


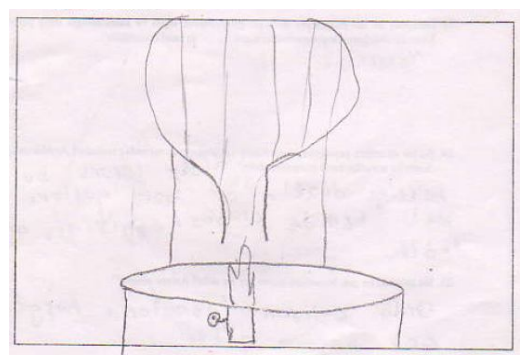

Figure 5. "When we press a button fire comes out and when it comes out air heats up. When the hot air gets into the balloon, the balloon rises. The flying of balloon attached my attention." $\mathrm{M}_{5}, 6^{\text {th }}$ grade.

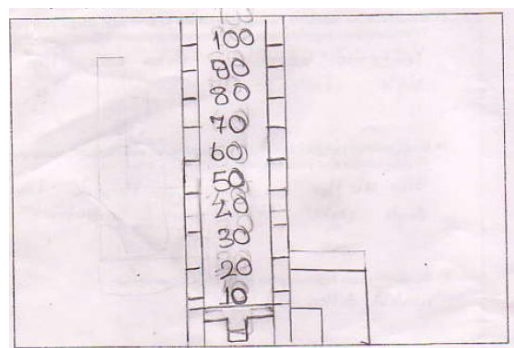

Figure 6. "There were different kinds of things in the museum. But the tool which measures human power was interesting. It was something like a bicycle. When the pedals were cycled, the ball rose. The more it rises, the more you are powerful." $\mathrm{F}_{66}, 7^{\text {th }}$ grade.

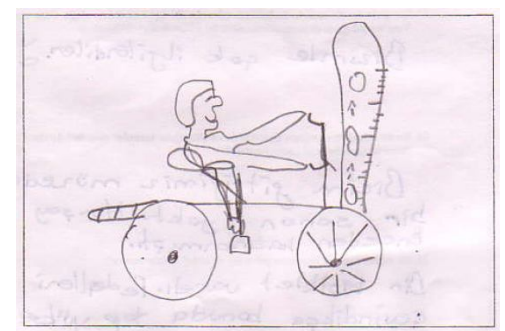

Figure 7. "There was a bicycle. When you cycled its pedals, the ball rose. This tool enjoyed me." $\mathrm{M}_{112}, 6^{\text {th }}$ grade.

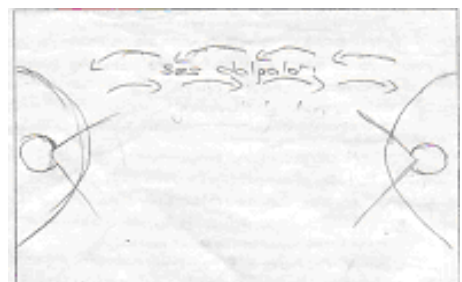

Figure 8. "The thing that enjoyed me the most was hearing the talks from a dish to another dish in Feza Gursey Science Center. When it was told something in one side, it could be heard from the other side clearly. " $\mathrm{F}_{64}, 6^{\text {th }}$ grade.

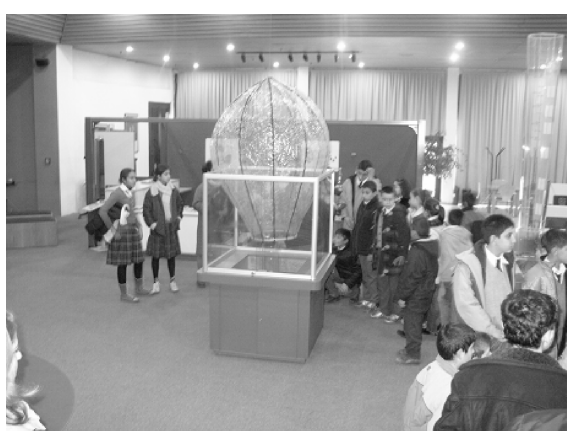

(Photo by A. E. Bozdoğan, 2006)

Hot Air Balloon Exhibition which gives information about how hot air balloon works, air- heat relation and balloons.

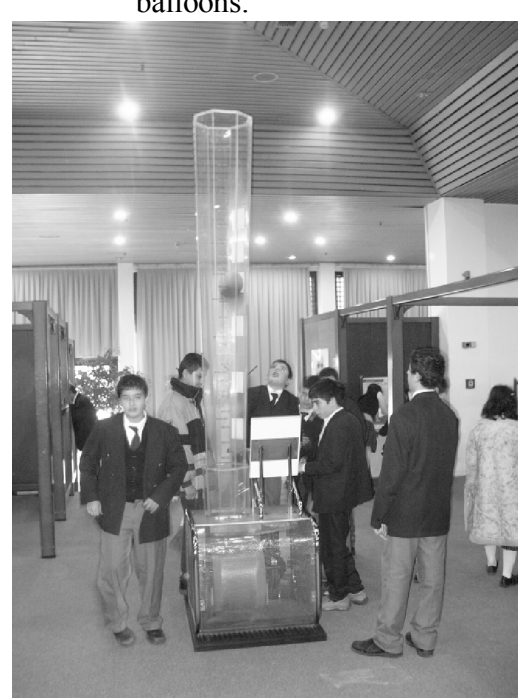

(Photo by A. E. Bozdoğan, 2006)

Aerodynamic Bicycle exhibition that shows approximately how much watt energy you have when the pedals are cycled.

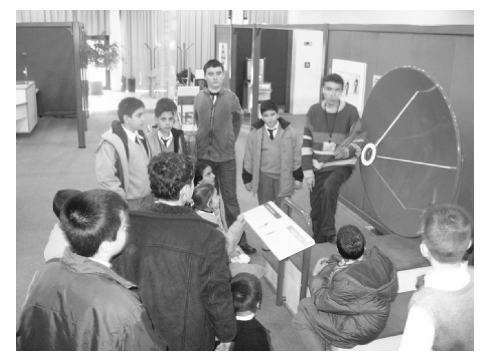

(Photo by A. E. Bozdoğan, 2006)

\section{Whispering Dishes Exhibition}

showing how sound waves produced in the focal point of the dish become audible by collecting them in the focal point of the other dish. 
Table 4. The distribution of the number of students about the interesting activities and exhibitions on Biology, Chemistry and Astronomy in FGSC.

\begin{tabular}{cclcc}
\hline Field & & \multicolumn{1}{c}{ Exhibition and Activity } & f \\
\hline \multirow{3}{*}{ Biology } & 1 & Human Heart And Lung & 16 \\
& 2 & Microscopes & Total & $\mathbf{2 7}$ \\
\hline \multirow{2}{*}{ Chemistry } & 1 & Shadow Tunnel & & 13 \\
& 2 & Nitrogen Demonstration & Total & $\mathbf{1 8}$ \\
\hline \multirow{2}{*}{ Astronomy } & 1 & Black Hole Model & & 8 \\
& 2 & Astronomy Slide & Total & $\mathbf{1 1}$ \\
\hline
\end{tabular}

Table 4 is shown that students visited FGSC interested secondly in $(n=27)$ activities and exhibitions about biology field of science. It is seen that students are interested in exhibitions and activities about the biology field with names "Human Heart And Lung" (figure 9) and "Microscopes" (figure 10). Students visited FGSC were interested $(n=18)$ in activities and exhibitions about physics field of science in the third place. It is seen that students are interested in exhibitions and activities in the chemistry field with names "Shadow Tunnel" (figure 11) and "Nitrogen Demonstration". When Table 4 is examined it is seen that students visited FGSC were interested $(n=11)$ in activities and exhibitions about astronomy field of science in the fourth place. It is seen that students are interested in exhibitions and activities in the astronomy field in the name of "Black Hole Model" (figure 12) and "Astronomy Slide".

Students' drawings about their interests in exhibitions and activities in biology, chemistry and astronomy fields are given figure 9, 10, 11 and 12 .

The relation between the grades of students attending research and science fields that they were interested in was examined with the Chi-squared method for two variables from nonparametric statistics and no significant relation was found between the grades of students and science fields that they were interested in $\left(\chi^{2}(6)=9.848, p>.05\right)$.

The relation between genders of students included in the study and the science fields that they were interested in was examined with the Chi-squared method for two variables from non- parametric statistics, and no significant relation between the gender and science fields that they were interested in $\left(\chi^{2}(3)=3.617, \mathrm{p}>.05\right)$.

Children's Perspectives of FGBM Settings and Experiences About Biology, Chemistry and Astronomy

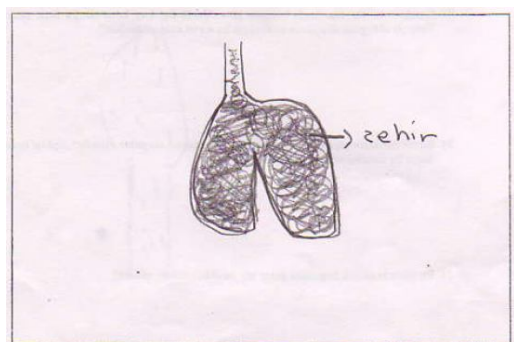

Figure 9. "The difference between the lungs of a man who smokes and who doesn't smoke and their dirty appearance taught that smoking is a bad habit. This never leaves my mind. " $\mathrm{M}_{47}, 6^{\text {th }}$ grade.

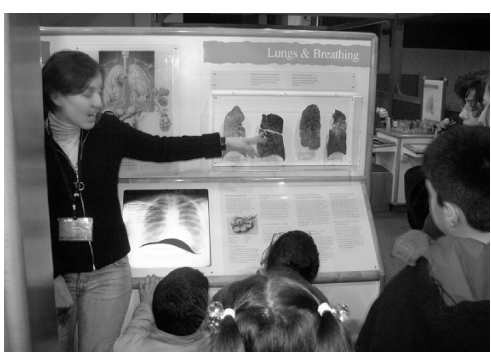

(Photo by A. E. Bozdoğan, 2006)

Human Heart and Lung exhibition in which the lungs of people who smoke and who don't smoke are compared. 


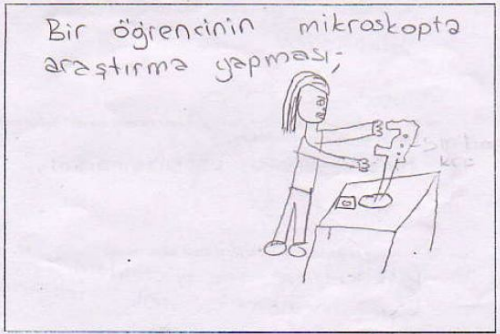

Figure 10. "The most pleasing thing for me was the microscope. Because it shows the plants and single cell to their last detail. It was very pleasing feeling. " $\mathrm{F}_{87}, 7^{\text {th }}$ grade.

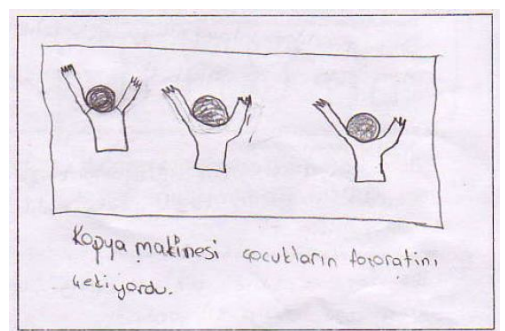

Figure 11. "There was a copy machine. It attached my attention the most. There was a small and dark room behind the curtain. The shapes of poses of us there were reflected on the wall. It was shining like switches when we turn off the lights at home. " $\mathrm{M}_{77}, 6^{\text {th }}$ grade.

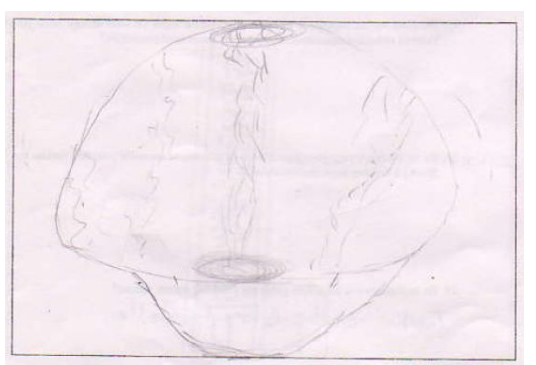

Figure 12. "The thing attracted me the most is the tool which shows how the stars disappear." $\mathrm{M}_{4}$, $6^{\text {th }}$ grade.

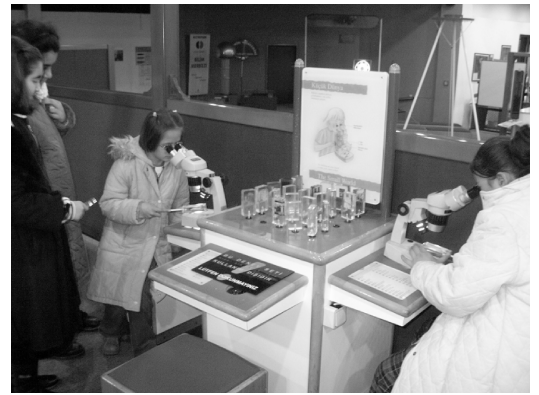

(Photo by A. E. Bozdoğan, 2006)

\section{Microscope Exhibition}

In which same 25 examples such as fruit fly, fish scale, snake skin and newspaper paper are shown with 3 microscopes

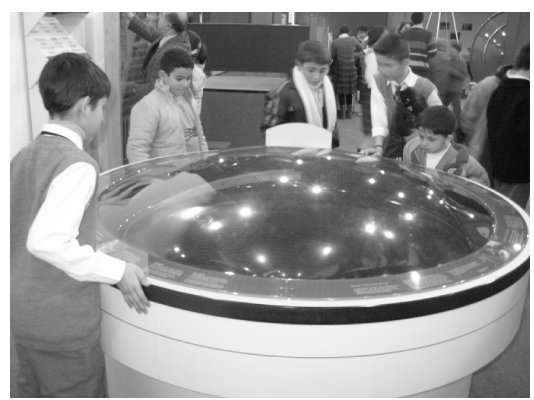

(Photo by A. E. Bozdoğan, 2006)

\section{Black Hole Model}

which gives visitors the opportunity to observe the movements of planets caught by attraction of a black hole and how it is swallowed by black hole.

It was seen that only 24 of the students included in the study knew the name of activity or exhibition they drew about. In addition, it was seen that 73 students didn't know the name of the exhibition or activity they drew and 25 misnamed them. It was seen that students wrote the names of exhibitions about biology correctly mostly (microscope, lung, model, etc.), and they didn't know or misnamed the exhibitions and activities on physics the most. There are some examples about this subject below. 
Table 5. Student perspectives about the names of the exhibitions and activities in FGSC

\begin{tabular}{|c|c|}
\hline $\begin{array}{c}\text { The name of the } \\
\text { exhibition or activity }\end{array}$ & Student Perspectives $(\mathrm{M}=$ Male, $\mathrm{F}=$ Female $)$ \\
\hline $\begin{array}{c}\text { The working principle } \\
\text { of Van De Graaff } \\
\text { Generator } \\
\text {-Electric } \\
\text { Demonstration }\end{array}$ & $\begin{array}{l}\text { "Electric Bulb" } \mathrm{F}_{104}, 8 \text { th grade. } \\
\text { "Electroshock Machine" } \mathrm{M}_{3} \text {, 6th grade. } \\
\text { "Electric Globe" } \mathrm{M}_{81}, \text { 6th grade. } \\
\text { "Electric Current" } \mathrm{M}_{12}, 7 \text { th grade. } \\
\text { "Electric Ball" } \mathrm{F}_{72}, 8 \text { th grade. } \\
\text { "Electric System" } \mathrm{F}_{83}, 7 \text { th grade. } \\
\text { "Electrical Tool that Erects Hair" } \mathrm{M}_{26}, \text { 8th grade. }\end{array}$ \\
\hline Plasma Ball Exhibition & $\begin{array}{l}\text { "Electric Globe" } \mathrm{F}_{60}, 6 \text { th grade. } \\
\text { "Magic Globe" } \mathrm{F}_{78} \text { 6th grade. } \\
\text { "Globe that Produce Electric When Touched" } \mathrm{F}_{97}, 8 \text { th grade. }\end{array}$ \\
\hline $\begin{array}{c}\text { Aerodynamic Bicycle } \\
\text { Exhibition }\end{array}$ & $\begin{array}{l}\text { "Energy Bicycle" } F_{8}, 6 \text { th grade. } \\
\text { "The tool in which Air Ball rises with the cycling Wheel" } \mathrm{M}_{76} \text {, 6th grade. } \\
\text { "Power Bicycle" } F_{120}, 6 \text { th grade. }\end{array}$ \\
\hline $\begin{array}{c}\text { Shadow Tunnel } \\
\text { Exhibition }\end{array}$ & $\begin{array}{l}\text { "Camera" } \mathrm{F}_{23}, 8 \text { th grade. } \\
\text { "Copy Machine" } \mathrm{M}_{77} \text {, 6th grade. }\end{array}$ \\
\hline $\begin{array}{c}\text { Whispering Dishes } \\
\text { Exhibition }\end{array}$ & “Satellite Dish” $\mathrm{M}_{30}, 8$ th grade. \\
\hline $\begin{array}{l}\text { Hot Air Balloon } \\
\text { Exhibition }\end{array}$ & "The Balloon that Expand with Heat" $\mathrm{M}_{31}, 8$ th grade. \\
\hline
\end{tabular}

\section{Discussion and Implications}

As a result of the study, it was seen that students visiting FGSC are interested in the physics the most $(n=66)$, and biology $(n=27)$, chemistry $(n=18)$ and astronomy $(n=11)$ fields follow this. But, when the literature is examined, it is seen that students are mostly interested in biology and astronomy, chemistry and physics fallow it. (Şimşek, 2007; Çepni, Küçük \& Ayvac1, 2006 \& Baram-Tsabari \& Yarden, 2005). It is seen that results of the present study are inconsistent with former studies. The most important reason for this is believed to the greater number of exhibitions about physics in FGSC and these tools and equipments are bigger and more attractive than others. Piscitelli and Anderson (2001) determined that the objects drawn by students after the museum tours are big objects (dinosaur, whale, tarantula, tank, transportation vehicles, etc.). They stated that the knowledge of children from past experiences is stored in the memory according to shape, size and measurement; and this shows the educational effects of the museums.

It is noted that only 24 of 122 students attending the research know the name of exhibition or activity that they drew. In order to solve this problem, exhibitions and activities can be provided in a shape and size which will attract students.

Students visiting the science centers in early ages affect their decision about heading towards which field of science and build a career in this field (Fadigan \& Hammrich, 2004). Because of this reason, taking students to these kinds of informal learning institutions will give them a chance to heading towards science fields which they describe as boring and difficult. Lively memories of the exhibitions and activities in the science center of the students visiting the science center after a time period of 6 to 18 months is the best proof for this. 


\section{References}

Baram-Tsabari, A., \& Yarden, A. (2005). Characterizing children's spontaneous interests in science and technology. International Journal of Science Education, 27, 803-826.

Barshinger, T., \& Ann, R. (1998). From volcanoes to virtual tours: Bringing museums to students through videoconferencing technology. Proceedings of the Annual Conference on Distance Teaching and Learning, ED422841 Eric Database 2005, 41-47.

Bozdoğan, A.E., \& Yalçın, N. (2007). İlköğretim öğrencilerinin fene karşı ilgi düzeylerinin değişmesinde bilim merkezlerinin rolü: Enerji Parkı. VI. Ulusal Sınıf Öğretmenliği Sempozyumu. Eskişehir, Türkiye: Anadolu Üniversitesi, 11-15.

Chin, C. (2004). Museum experience - a resource for science teacher education. International Journal of Science and Mathematics Education, 2, 63-90.

Cox-Petersen, A. M. (1999). Dive into research at the aquarium. Science Activities, 36 (3), 34-36.

Cepni, S., \& Küçük, M., \& Ayvacı, H. Ş. (2006). Ilköğretim 4. sınıf öğrencilerinin fen bilgisi dersine karsi ilgilerinin belirlenmesi. VI. Ulusal Fen Bilimleri ve Matematik Eğitimi Kongresi Bildiriler Kitab1. (Cilt 1), 258-265.

Davies, K. (1997). The challenge of materials gallery: A new exhibition at the science museum. New Materials, 169-172.

Fadigan, K. A., \& Hammrich, P. L. (2004). A longitudinal study of the educational and career trajectories of female participants of an urban informal science education program. Jourmal of Research in Science Teaching, 41, 835-860.

Falk, J. H., \& Adelman, L. M. (2003). Investigating the impact of prior knowledge and interest on aquarium visitor learning. Journal of Research in Science Teaching, 40, 163-176.

Gerber, B.L., \& Cavallo, A.M.L., \& Marek, E. A. (2001). Relationships among informal learning environments, teaching procedures and scientific reasoning ability. International Journal of Science Education, 23, 535- 549.

Griffin, J. (2004). Research on students and museums: looking more closely at the students in school groups. Science Education, 88(Supp.-1), 59-70.

Guisasola, J., \& Morentin, M., \& Zuza, K. (2005) School visits to science museums and learning sciences: A complex relationship. Physics Education, 40, 544-549.

Hannu, S. (1993). Science centre education. motivation and learning in informal education. Helsinki University Department of Teacher Education. Finland. (Unpublished Doctoral Dissertation).

Jarvis, T., \& Pell, A. (2002). The effect of the challenger experience on elementary children's attitudes to science. Journal of Research in Science Teaching, 39, 979-1000.

Kelly, J. (2000). Rethinking the elementary science methods course: A case for content, pedagogy, and informal science education. Intenational Journal of Science Education, 22, 755-777.

Lemelin, N., \& Bencze, L. (2004). Reflection-on-action at a science and technology museum: findings from a university-museum partnership. Canadian Journal of Science, Mathematics and Technology Education, 4, 467-481.

Livingstone, P., \& Pedretti, E., \& Soren, B. J. (2001). Comment cards and visitors' understanding of the cultural context of science. Annual Meeting of the American Association of Museums. (Research Report).

Martin, L. M. W. (2004). An emerging research framework for studying informal learning and schools. Wiley Periodicals, Inc. 71-82.

Panizzon, D., \& Gordon, M. (2003). Mission possible: A day of science, fun and collaboration. Australian Primary \& Junior Science Journal, 19, 9-14.

Paris, S. G., \& Yambor, K. M. \& Packard, B. W. (1998). Hands-on biology: A museum-schooluniversity partnership for enhancing students' interest and learning in science. Elementary School Journal, 98, 267-288.

Pedretti, E. G. (2004). Perspectives on learning through research on critical issues-based science center exhibitions. Science Education, 88(Suppl. 1), 34- 47.

Piscitelli, B., \& Anderson, D. (2001). Young children's perspectives of museum settings and experiences. Museum Management and Curatorship, 19, 269-282.

Rapp, W. (2005). Inquiry-based environments for the inclusion of students with exceptional learning needs. Remedial And Special Education, 26, 297-310.

Şimşek, C. L. (2007). Öğrenciler fen ve teknoloji dersinde ne öğrenmek istiyorlar? VI. Ulusal Sınıf Öğretmenliği Sempozyumu, 39-43. Eskişehir, Türkiye: Anadolu Üniversitesi. 
Tenenbaum, H. R., \& Rappolt-Schlichtmann, G., \& Zanger, V. V. (2004). Children's learning about water in a museum and in the classroom. Early Childhood Research Quarterly, 19, 40-58.

Wellington, J. (1990). Formal and informal learning in science: The role of the interactive science centres. Physics Education, 25, 247-252.

White, R. \& Gunstone, R. (1992). Probing understanding. London: Falmer Press.

$\mathrm{Yu}$, J. (1999). The national science and technology museum of Taiwan. Technology and Culture, 40, 107-113.

Received 12 July 2007; accepted 20 August 2007

\author{
Aykut Emre Bozdogan \\ Ahi Evran Üniversty, Education Faculty, Department of Science Education, \\ Terme St. 40100 Kirsehir, Turkey \\ E-mail: emreaykut@yahoo.com
}

